\section{Chemical Literature}

A Guide to the Literature of Chemistry. 2d ed. By E. J. Crane, Austin M. Patterson, and Eleanor B. Marr. New York: John Wiley \& Sons, 1957. 397p. $\$ 9.50$.

Thirty years ago E. J. Crane and Austin M. Patterson put out a splendid volume, $A$ Guide to the Literature of Chemistry, which attempted to help the chemist avoid wasting valuable materials and more valuable time in the laboratory in determining what had been already published. The plan of this book of thirty years ago was to divide the chemical literature into three points of view, namely those of production, distribution, and use.

One will find, on turning to the new edition of $A$ Guide to the Literature of Chemistry, in the chapter devoted to "Problem and Objectives," that the emphasis remains the same; however, in the preface to the new edition, one finds the statement by Miss Eleanor B. Marr, the new joint author, that the second edition of the Guide is intended to be used both as a reference work and as a textbook. In agreement with Miss Marr, this second edition is definitely a reference work and, thus, similar in objective to the first edition. However, the new edition is a thorough and detailed analysis of many items that would be very difficult to present to the beginning student. It would seem that this work is primarily a reference work of great detail, which makes it most usable to the researcher who has had an introduction to chemical literature. From her chapter "Procedure in Literature Searches" one can see that Miss Marr is aware of such an unevenness when she writes,

Within this work, there are some errors in respect to dates of publications. Some specific omissions follow: The statement on page 172 that Chemical Abstracts is the only abstract journal that covers Japanese patents should be changed to include the Referativnyi Zhurnal Khimiya, and other parts. On page 173, the statement that the Chemisches Zentralblatt stopped publishing tables of patent equivalents in 1945 should be changed to point out that this service was resumed in 1953. A statement on page 187 neglects to mention that there are two Facts for Industry, one published by the U.S. Tariff Commission, dealing with organic chemicals, and the other by the U.S. Bureau of the Census, dealing with inorganic chemicals. On page 220 is omitted the biographic work American Men of Science, appearing in three extensive volumes and of the greatest use.

This book has retained many of the excellent features of the old edition, and most parts throughout have been enlarged. This new edition is still primarily for the scholar, the reference librarian, and those having passed through an elementary course in chemical literature. As a reference work, this new edition is the most important upto-date book available on the subject and should be bought by anyone working with the literature of chemistry.-James van Luik, Purdue University Library.

\section{Russian Bibliography}

Zdobnov, N. V. Istoriia russkoi bibliografii do nachala XX veka. Izdanie tret'e. Moscow: Gosudarstvennoe izdatel'stvo kul'turno-prosvetitel'noi literatur'i, 1955. 607p. 14R. $80 \mathrm{~K}$.

Ten years after publication of the first edition, the third edition of N. V. Zdobnov's History of Russian Bibliography up to the Beginning of the Twentieth Century has appeared. The editor of this edition, Professor B. S. Bodnarskii, has revised the text slightly and added a few portraits of outstanding Russian bibliographers and facsimiles of the title pages of their works. However, the history of Russian bibliography of the twentieth century and of Soviet epoch is still unwritten, since Zdobnov's death prevented the completion of this great work.

Before Zdobnov published his work, there had been several other works on Russian bibliography, such as those of K. N. Derunov, A. I. Malein and A. G. Fomin. However, Zdobnov points out in his preface that these earlier books were not written from the Marxist point of view, which he follows.

However, Zdobnov has not given any completely new Marxist view on bibliography, as he has not been original (and under exist- 
ing conditions in the Soviet Union could not be). He has simply applied the old Marxist view of partisanship against objectivism in literature to the studies of bibliography.

In preparing his book, Zdobnov had to consult over 5,000 books and about 30,000 articles in sixty bibliographical and 700 general magazines of the eighteenth and nineteenth centuries. He divided his book into five parts: (1) the beginning period of Russian bibliog- raphy, from the eleventh to the seventeenth century; (2) the eighteenth century; (3) the first half of the nineteenth century; (4) the 1850 's and 1860 's; and (5) from the 1870 's to the beginning of the twentieth century. This third edition of the book was published in 10,000 copies, an indication of widespread interest in the history of bibliography in the U.S.S.R.-Milimir Drazic, Northwestern University Library.

\section{Argentine Libraries}

\section{(Continued from page 402)}

works in a convenient place. In short, whether or not users receive assistance and the quality of such service too often depend on chance, as opposed to organized reference work. However, as evidence of growing awareness of the importance of such work, one might cite the following: (1) use of enlarged book budgets to build up holdings of dictionaries, encyclopedias, bibliographies, handbooks, and the like, and (2) plans to establish reference or reference-circulation positions as soon as possible in several libraries now lacking such posts. The forthcoming publication of the first work in Spanish on reference books, by Josefa Emilia Sabor, librarian of the Faculty of Philosophy and Letters at Buenos Aires, should stimulate further interest in this area of librarianship.

The interpretation of public services has evolved unevenly in Argentina. Libraries utilize exhibits and displays, sponsor lectures on occasion and succeed in obtaining publicity in local newspapers and on radio stations. On the other hand, instruction in the use of the library, handbooks, and guides to collections remain relatively unexploited.

\section{Conclusion}

A review of the present organization, resources, and services of Argentine university libraries reveals a number of closely discernible trends. The first of these is the growing amount of centralization and coordination in each system; this may eventually lead to centralized library service, especially if some institutions carry out plans to build university cities. Second, if present funds continue to be available, these libraries will make substantial additions to their already important resources. Third, there is a tendency to re-evaluate library techniques and services and to reorganize them along more modern lines when necessary. All of these are positive developments. Assuming that such present problems as lack of central catalogs, lacunae in holdings of recent foreign publications, and inadequate space will be solved (this is not a small task, but present signs point to success), one can look forward expectantly to Argentine university libraries' serving better the growing needs of their faculties and students. 